\title{
Table of cases
}

\section{INTERNATIONAL JURISDICTIONS}

\section{International Court of Justice}

Ahmadou Sadio Diallo (Republic of Guinea v. Democratic Republic of the Congo),

Judgment, ICJ Rep. (2012) p. 324

Ahmadou Sadio Diallo (Republic of Guinea v. Democratic Republic of the Congo),

Judgment, ICJ Rep. (2010) p. 639 $141-142,160-161$

Applicability of Article VI, Section 22 of the Convention on the Privileges and

Immunities of the United Nations, Advisory Opinion, ICJ Rep. (1989)

p. 177

Application for Review of Judgment No 158 of UNAT, Advisory Opinion, ICJ Rep.

(1973) p. 166 145

Application for Review of Judgment No 273 of UNAT, Advisory Opinion, ICJ Rep.

(1982) p. 325

Application for Review of Judgment No 333 of UNAT, Advisory Opinion, ICJ Rep.

(1987) p. 18

Application of the Convention on the Prevention and Punishment of the Crime of

Genocide (Bosnia and Herzegovina v. Serbia and Montenegro), Judgment, ICJ

Rep. (2007) p. 43

Armed Activities on the Territory of the Congo (New Application: 2002)

(Democratic Republic of the Congo v. Rwanda), Judgment of 3 February 2006

(Jurisdiction of the Court and Admissibility of the Application), ICJ Rep.

(2006) p. 32 90

Case concerning the Arrest Warrant of 11 April 2000 (Democratic Republic of the

Congo v. Belgium), ICJ Rep. (2002) p. 3

Certain Expenses of the United Nations, Advisory Opinion, ICJ Rep. (1962)

p. 151

Difference Relating to Immunity from Legal Process of a Special Rapporteur of the

Commission on Human Rights, Advisory Opinion, ICJ Rep (1999) p. 62 ..... 9, $144-145,245$

Effect of Awards of Compensation Made by the United Nations Administrative

Tribunal, Advisory Opinion, ICJ Rep. (1954) p. 57 $119-121,164$

Interpretation of the Agreement of 25 March 1991 between the WHO and Egypt,

Advisory Opinion, ICJ Rep. (1980) p. 73 71,123

Judgments of the I.L.O. Administrative Tribunal, Advisory Opinion, ICJ Rep.

(1956) p. 97 146,171 
Judgment No. 2867 of the Administrative Tribunal of the International Labour Organization upon a Complaint Filed against the International Fund for Agricultural Development, Advisory Opinion, ICJ Rep. (2012), p. 10 ...... 146,

Jurisdictional Immunities of the State (Germany v. Italy, Greece Intervening), Judgment, ICJ Rep. (2012) p. 99 239, 265, 301-302, 319, 331

Legal Consequences of the Construction of a Wall in the Occupied Palestinian

Territory, Advisory Opinion, ICJ Rep. (2004) p. 136 76,141

Legality of the Use by a State of Nuclear Weapons in Armed Conflict, Advisory

Opinion, ICJ Rep. (1996) p. 66 240

North Sea Continental Shelf Case (Federal Republic of Germany v. Denmark;

Federal Republic of Germany v. the Netherlands), Judgment, ICJ Rep.

(1969) p. 3

Reparation for Injuries Suffered in the Service of the United Nations, Advisory

Opinion, 11 April 1949, ICJ Rep. (1949) p. 174 $19,71,233$

\section{Permanent Court of Arbitration}

Award, Polis Fondi Immobiliari Di Banche Popolare Sgr.P.A (Italy) v. International Fund for Agricultural Development, Case No. 2010-8 41,149

\section{Permanent Court of Justice}

Case Concerning the Factory at Chorzów, 13 September 1928, Publications of the PCJI Series A No. 17

Mavrommatis Palestine Concessions Case (Greece v. the United Kingdom), 30

August 1924, Publications of the PCJI Series A No. 17 131,261

\section{Court of Justice of the European Union}

C-155/79 AMandS v. Commission EU:C:1982:157 ......................................... 57

C-416/98 Commission v. Nea Energeiaki Technologia EU:C:2002:104 ............ 183

C-44/79 Hauer v. Land Rheinland-Pfalz EU:C:1979:290 ................................. 57

C-42/94 Heijmei v. Parliament EU:C:1995:163 ............................................ 183

C-23/76 Pellegrini and CS v. Commission and Flexon Italia S.p.A.

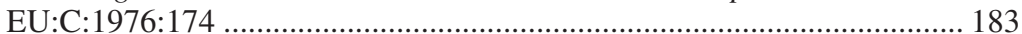

C-370/12 Pringle v. Government of Ireland, Ireland and the Attorney General

EU:C:2012:756 67,222

C-4/73 Nold v. Commission EU:C:1974:51 ..................................................... 57

C-399/11 Stefano Melloni v. Ministerio Fiscal EU:C:2013:107 ......................... 69

Joined Cases C-8/15 P to C-10/15 P Ledra Advertising v. Commission and ECB

ECLI:EU:C:2016:701 $62,221-222$

Joined Cases C-402/05 P and C-415/05 P Kadi and Al Barakaat International

Foundation v. Council and Commission EU:C:2008:461 67,307

Opinion 2/13 Accession of the European Union to the European Convention for the Protection of Human Rights and Fundamental Freedoms

EU:C:2014:2454 $68-69,140-141,154,197$ 


\section{General Court of the European Union (former Court of First Instance)}

T-306/01 Ali Yusuf and Al Barakaat International Foundation v. Council of the European Union and Commission of the European Communities

ECLI:EU:C:2004:150

T-315/01 Yassin Abdullah Kadi v. Council of the European Union and Commission of the European Communities ECLI:EU:T:2005:332

\section{European Commission on Human Rights}

Beer and Regan v. Germany, App. No. 28934/95 258

Confédération Française Démocratique du Travail v. The European Communities, alternatively: their Member States a) jointly and $b$ ) severally, App.

No. 8030/77

Spaans v. the Netherlands, App. No. 12516/86, Decision on Admissibility ....... 230,

van der Peet v. Germany, App. No. 26991/95, Decision on Admissibility ........... 258

Waite and Kennedy v. Germany, App. No. 26083/94 258,260

Xv. Federal Republic of Germany, App. No. 4523/70 100

Zand v. Austria, App. No. 7360/76, Report of 12 October 1978 113

\section{European Court of Human Rights}

Airey v. Ireland, App. No. 6289/73 96,108

Alv. Italy, App. No. $41387 / 98$ 263

Al-Adsani v. the United Kingdom, App. No. 35763/97 ...................................... 301

Al-Dulimi and Montana Management Inc. v. Switzerland, App. No. 5809/08 .... 307

Al-Jedda v. the United Kingdom, App. No. 27021/08 $22,298,311$

Al-Skeini and others v. the United Kingdom, App. No. 55721/07 310-311

Bankovic et al. v. Belgium et al., App. No. 52207/99 311

Beer and Regan v. Germany, App. No. 28934/95 $107,127,129,258-259,265$,

292, 300, 332

Joined Cases Behrami and Behrami v. France, App. No. 71412/01 and Saramativ.

France, Germany and Norway, App. No. 78166/01 17, 21-22, 29-30, $154-155,241,298,301$

Bellet v. France, App. No. 23805/94 108

Bosphorus Hava Yolları Turizm ve Ticaret Anonim Şirketi v. Ireland, App. No. 45036/98 29-30

Bryan v. the United Kingdom, App. No. 19178/91 .......................................... 110

Campbell and Fell v. the United Kingdom, App. Nos. 7819/77 and 7878/77 ...... 109,

Coëme and others v. Belgium, App. Nos. 32492/96, 32547/96, 32548/96, 33209/96 and $33210 / 96$

De Haes and Gijsels v. Belgium, App. No. 19983/92 ........................................ 114

Delcourt v. Belgium, App. No. 2689/65 .................................................... 100

Deweer v. Belgium, App. No. 6903/75 ......................................................... 112

Fey v. Austria, App. No. 14396/88 .......................................................... 110 
Findlay v. the United Kingdom, App. No. 22107/93

$110-113,133$

Gasparini v. Italy and Belgium, App. No. 10750/03

$29,125,177,262$

Golderv. the United Kingdom, App. No. 4451/70 $91,95-96$

Hauschildt v. Denmark, App. No. 10486/83 169

Helmers v. Sweden, App. No. 11826/85 114

Hornsby v. Greece, App. No. 18357/91 115

Iatridis v. Greece, App. No. $31107 / 96$ .95

Jelicic v. Bosnia and Herzegovina, App. No. 41183/02 ..................................... 97

Incal v. Turkey, App. No. 22678/93 111

Isayeva, Yusupova and Bazayeva v. Russia, App. Nos. 57947/00; 57948/00 and 57949/00 95

Khashiyev and Akayeva v. Russia, App. Nos. 57942 and 57945/00 95

Klauseckerv. Germany, App. No. 415/07 264,322

König v. Germany, App. No. 6232/73 100

Kudta v. Poland, App. No. 30210/96 .95

Kyriakoula Stephens v. Cyprus, Turkey and the United Nations, App. No 45267/06, 11 December 2008 154

Le Compte, Van Leuven en De Meyere v. Belgium, App. Nos. 6878/75 and $7238 / 75$

Lopez Cifuentes v. Spain, App. No. 18754/06 264

Markovic and others v. Italy, App. No. 1398/03 $311-313$

Matthews v. the United Kingdom, App. No. 24833/94 28

Nada v. Switzerland, App. No. 10593/08 155,307

Nortier v. the Netherlands, App No. 13924/88 .............................................. 169

Oleykinov v. Russia, App. No. 36703/04 ..................................................... 250

Osman v. the United Kingdom, App. No. 23452/94 ........................................... 126

Perez v. Germany, App. No. 15521/08 ............................................................. 264

Pullar v. the United Kingdom, App. No. 22399/93 ............................................ 110

Richard Chapman v. Belgium, App. No. 39619/06 ................... 177, 263-264, 279

Senerv. Turkey, App. No. 26680/95

Sramek v. Austria, App. No. 8790/79 112

Stichting Mothers of Srebrenica and Others against the Netherlands, App. No. 65542/12 ........ 17, 128, 227, 241-242, 265, 272, 280, 297-303, 307, 308, 316, 319,331

Tanrikulu v. Turkey, App. No. 23763/94 .95

Trigo Saraiva v. Portugal, App. No. 28381/12 169

Waite and Kennedy v. Germany, App. No. 26083/94

122 , 124-129, 133, 177, 258-260, 263, 265-266, 271-280, 284-288, 292, 299-303, 308, 319, 332-333

\section{Inter-American Court of Human Rights}

Case of Baena-Ricardo et al. v. Panama, 2 February 2001, Series C No. 72 .......... 94

Case of Las Palmeras v. Colombia, 6 December 2001, Series C No. 90 ................. 94

Case of the Constitutional Court (Aguirre Roca v. Peru), 31 January 2001,

Series C No. 71 .93

García Lucero et al. v. Chile, 28 August 2013, Series C No. 267 93 
Goiburú et al.v. Paraguay, 22 September 2006, Series C No. 153 .................... 105

Ivcher Bronstein v. Peru, 6 February 2001, Series C No. 74 ................................. 96

La Cantuta v. Peru, 29 November 2006, Series C No. 162 ................................ 105

Massacre of Mapiripán v. Columbia, 15 September 2005, Series C No. 134 ........ 93

Massacre of Pueblo Bello v. Colombia, 31 January 2006, Series C No. 140 ... 93, 96,

Velásquez Rodríguez v. Honduras, 26 June 1987, Series C No. 4 ......................... 93

Zambrano Vélez et al. V. Ecuador, 4 July 2007, Series C No. 166 ......................... 94

\section{International Criminal Tribunal for the Former Yugoslavia}

Prosecutorv. Furundzija, Case IT-95-17/1-T, Judgment of 10 December 1998 ... 90 Prosecutor v. Tadic, IT-94-1-A-AR77, 27 February 2001 ................................. 105

\section{International Criminal Tribunal for Rwanda}

Prosecutorv. Rwamakuba, Decision on Appropriate Remedy, 2007, ICTR-98-44C-T

\section{Special Tribunal for Lebanon}

In the Matter of El Sayed, Case No. CH/PRES/2010/01, Order of the President Assigning Matter to Pre-Trial Judge, 15 April 2010

\section{Special Court of Sierra Leone}

Prosecutor v. Norman, Kallon, and Gbao, Case No. SCSL-2003-09-PT, Decision on the Application for a Stay of Proceedings and Denial of Right to Appeal, 4 November 2003

\section{Human Rights Advisory Panel}

\section{Decisions}

Balaj and Others, Case No. 04/07, 31 March 2010

N.M. and Others v. UNMIK, Case No. 26-08, 31 March 2010 ................... 190, 209

NTP Bujari (as Petrol) v. UNMIK, Case No. 311/09, 6 December 2012 .............. 209

\section{Opinions}

N.M. and Others v. UNMIK, Case No. 26/08, 26 February 2016 ........................ 210

S.C. v. UNMIK, Case No. 02/09, 6 December 2012 ......................................... 209

\section{International Tribunal for the Law of the Sea}

Conservation and Sustainable Exploitation of Swordfish Stocks in the South-Eastern Pacific Ocean (Chile/European Union), Case No. 7 


\section{International Administrative Tribunals}

\section{International Labor Organization Administrative Tribunal}

Awoyemi v. UNESCO, Judgment No. 1756 (1988) $38,66,174$

Breuckmann v. European Organisation for the Safety of Air Navigation

(Eurocontrol) No. 2, Judgment No. 322 (1977)

Bustos v. Pan American Health Organization, Judgment No. 701 (1985)

Cardenas Aguila v. European Southern Observatory, Judgment No. 1302

Chadsey v. Universal Postal Union, Judgment No. 122 (1968)

Franks and Vollering, Judgment No. 1333 (1994) 118

Geisler and Wenzel v. EPO, Judgment No. 899 (1988) $66,87,174$

J.M.W. v. EPO, Judgment No. 2292 (2004) 38

M.R. v. EPO, Judgment No. 2127 (2002) $66,87,174$

Rubio v. Universal Postal Union, Judgment No. 1644 (1997) 175 118

\section{United Nations Administrative Tribunal}

Irani v. Secretary-General of the United Nations, Judgment No. 150 (1971) ...... 180

Kaplan v. UN Secretary-General, Judgment No. 19 (1953) ................................ 36

Teixeira v. Secretary-General of the United Nations, Judgment No. 230 (1977) 180

\section{United Nations Appeals Tribunal}

Chen v. Secretary-General of the United Nations, Judgment No. 2011-UNAT-107, 11 March 2011

Tabari v. Commissioner General of the United Nations Relief and Works Agency for Palestine Refugees, Judgment No. 2010-UNAT-030, 30 March 2010 170

\section{United Nations Dispute Tribunal}

Judgments

Basenko v. Secretary-General of the United Nations, Judgment No. UNDT/2010/ 145, 13 August 2010 55,180

Bertucci v. Secretary-General, Judgment No. UNDT/2010/080, 11 March 2011 168

Campos v. Secretary-General of the United Nations, Judgment No. UNDT/2009/ 005, 12 August 2009 $109-110,169$

Obdijn v. Secretary-General of the United Nations, Judgment No. UNDT/2011/032, 10 February 2011

Tadonki v. Secretary of the United Nations, Judgment No. UNDT/2009/058, 30 October 2009 166,170

Wamalala v. Secretary-General of the United Nations, Judgment No. UNDT/2012/ 052, 17 April 2012 


\section{Orders}

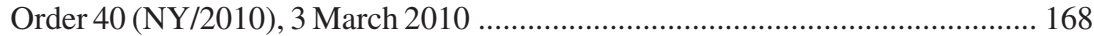

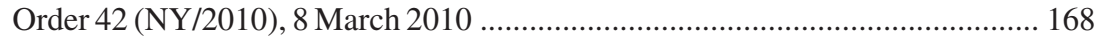

Order 43 (NY/2010), 8 March 2010 .................................................................. 168

Order 44 (NY/2010), 9 March 2010 ................................................................. 168

\section{World Bank Administrative Tribunal}

de Merode v. IBRD, Decision No. 1, WBAT Reports (1981)

65,178

Mendaro v. IBRD, Decision No. 26, WBAT Reports (1985)

$65-66,178,231,243$,

315,317

\section{NATIONAL JURISDICTIONS}

\section{Austria}

Company Baumeister Ing Richard L v. O, 14 December 2004, 10 Ob 53/04 y, ILDC 362 (AT 2004)

\section{Argentina}

Supreme Court, Washington Julio Efraín Cabrera v. Comisión Técnica Mixta de Salto Grande, 305 Fallos de la Corte Suprema 2150 (1983) 104,294

Supreme Court, Duhalde v. Organización Panamericana de la Salud-

Organización Mundial de la Salud - Officina Sanitaria Panamericana,

D.73.XXXIV, 322 Fallos de la Corte Suprema 1905 (1999) 104,295

Supreme Court, Fibraca Constructora S.C.A. v. Comisión Técnica Mixta de Salto Grande, CSJN, 7 July 1993, 316 Fallos de la Corte Suprema (1669)

\section{Belgium}

Brussels Court of Appeal, Belgian State v. S.A. International Hotels Worldwide, 29 June 2012, RG 2011/AR/558 (unpublished)

Brussels Court of Appeal, Manderlier v. Organisation des Nations Unies et l'Etat Belge, 15 September 1969, 25 Revue critique de jurisprudence belge (1971) pp. 449-462 (note P. De Visscher), 69 ILR 139

Brussels Court of Appeal, SA Energies Nouvelles et Environnement v. Agence Spatiale Européenne, No. 2011/2013, 2006/AR/1480, ILDC 1729 (BE 2011)

Brussels Court of First Instance, El Hamidi \& Chlih v. NATO, 22 October 2012, 9 Journal des Tribunaux (2014) pp. 156

Brussels Court of First Instance, Jefara and others v. NATO, Case No. 12/966/C, 26 April 2013, Judgment on interim proceedings, unpublished 309-313

Brussels Court of First Instance, Manderlier v. Organisation des Nations Unies et l'État Belge (Ministre des Affaires Etrangères), 11 May 1966, Journal des Tribunaux (1966) pp. 721-724; (1972) 45 ILR 446 ...... 42, 193, 236, 237, 316 
Brussels Court of First Instance, Mukeshimana-Ngulinzira and others v. Belgium and others, RG No 04/4807/A and 07/15547/A, 8 December 2010, ILDC 1604 (BE 2010)

Brussels Court of First Instance, S.A. Energies Nouvelles et Environnement v. ESA, 1 December 2005, ILDC 1229 (BE 2005) 266-267

Brussels Court of First Instance, S.A. International Hotels Worldwide v. S.A. Grandvision Belgium, Journal des Tribunaux (2011) pp. 655-657 269

Brussels Labour Court of Appeal, Lutchmaya v. ACP Secretariat, 4 March 2003, Journal des Tribunaux (2003) p. 684, ILDC 1363 (BE 2003) 232,277

Brussels Labour Court of Appeal, Siedlerv. Western European Union, 17 September 2003, Journal des Tribunaux (2004) p. 617 (note E. David), ILDC 53 (BE 2003) 277-278

Court of Cassation, General Secretariat of the ACP Group ACP Group., 21

December 2009, Cass. Nr. C.07.0407.F, ILDC 1576 BE 2009 .... 225, 276, 278

Court of Cassation, General Secretariat of the ACP Group v. Lutchmaya, 21

December 2009, No. C.03.0328.F, ILDC 1573 BE 2009 $100,225,232$, $276-277,333$

Court of Cassation, ING Belgium v. B.I., 2 March 2007, Pasicrisie I (2007) p. 443

Court of Cassation, League of Arab States v. TM, 12 March 2001, Journal des

Tribunaux (2001) p. 610, ILDC 42 (BE 2001) 231

Court of Cassation, Western European Union v. Siedler, 21 December 2009, No.

S.04.0129.F, Pasicrisie Belge (2009) p. 3143, ILDC 1625 (BE 2009) ......... 39, $232,267,269,276-279$

\section{Brazil}

Appellate Labor Tribunal for the Tenth Region, Fernandez Duarte v. OAS, Proceso 00101 2004-006-10-00-6 (2004) 285

Superior Labor Court, Cilene Maria Holanda Salaoio v. UNESCO,

RR-574-2004-013-10-001, 26 September 2007 254

Superior Labor Court, Estevao de Castro Melo v. UN-UNDP, RR-295/ 2004-019-10-00, 1 April 2009 254

\section{Canada}

Supreme Court, Amaratunga v. Northwest Atlantic Fisheries Organization, 29

November 2013, $2013 \mathrm{scc} 66$ 233

Supreme Court, Valente [1985] SCR 673, 23 CCC 3d 193 (1985)

\section{Colombia}

Constitutional Court, Judgment No. C-788/2011, Case N. LAT-365, Revisión de constitucionalidad del 'Acuerdo de Cooperación y Régimen de Privi legios e Inmunidades entre la Organización Internacional para las Migraciones y el Gobierno de la República de Colombia', y de la Ley 1441 del 23 de febrero de 2011, por medio de la cual fue aprobado, 20 October 2011 
Constitutional Court, Judgment N. C-137/1996, Case N. LAT-052, Revisión de la Ley 208 de 1995 'Por medio de la cual se aprueba el "Estatuto del Centro Internacional de Ingeniería Genética y Biotecnología” hecho en Madrid el 13 de septiembre de 1983', 9 April 1996

Council of State, Interside v. Ministerio de Agricultura y Secretaría Ejecutiva del Convenio Andrés Bello, Sala de lo Contencioso Administrativo del Consejo de

Estado, 26 March 2009 $235-236$

Council of State, Rojas Robles c. Ministerio de Relaciones Exteriores Judgment N.

11044, Case N. IJ-001, 25 August 1998 255,324

\section{Cyprus}

Supreme Court, Stavrinou v. United Nations and Commander of the United Nations Force in Cyprus, ILDC 929 (CY 1992) 255,324

\section{Denmark}

Court of Second Instance for the Eastern Circuit (Østre Landsret), sitting as a Court of First Instance, The Investment \& Finance Company of 11 January 1984 Ltd v. UNICEF, U 2000478 Ø; ILDC 64 (DK 1999) 254

\section{France}

Council of State, Minister of Foreign Affairs v. Dame Burgat and others, 29 October 1976, Recueil (1977) p. 453

Court of Appeal of Paris, Communauté Economique des Etats de l'Ouest Africain (CEDAO) v. Bank of Credit and Commerce International (BCCI), 13 January 1993, 120 Journal de droit international (1993) p. 353

Court of Appeal of Paris, Mazéas v. Latin Union, 7 December 2000, unpublished

Court of Appeal of Paris, UNESCO v. Boulois, 19 June 1998, Revue de l'arbitrage (1999) p. 343

Court of Cassation, African Development Bank v. Degboe, 25 January 2005, (2005) ILDC 778 FR 2005 106,291

Court of Cassation, de Beaugrenier v. UNESCO, 11 February 2009, 4 Journal de Droit International (2009) pp. 1247-1274

Court of Cassation, Hintermann v. Western European Union, 14 November 1995 , Journal du Droit International (1997) p. 141

Court of Cassation, Illemassene v. OECD, 29 September 2010, No. 09-41030, ILDC 1749 (FR 2010) 291,293

Court of Cassation, Mazéas v. Latin Union, 30 September 2003, Juris-Classeur Périodique (2004) II 10102

Court of Cassation, State of Israel v. National Iranian Oil Company, 1 February

2005, Revue critique de Droit international privé (2006) p. 140

Court of Cassation, Xv. EUTELSAT, 5 June 2001, Bulletin (2001) p. 161 291 


\section{Germany}

Amtsgericht Bonn, Xv. Western European Union, 23 August 1961, Monatsschrift für Deutsches Recht (1962) p. 315

Federal Constitutional Court, Application of Wünsche Handelsgesellschaft, 22 October 1986, 2 BvR 197/83; 3 Common Market Law Review (1987) p. 225 (Solange II) 28,325

Federal Constitutional Court, B. and others v. the judgment of the [Administrative] Tribunal of the International Labour Organisation of 16 July 2003 -No. 2228 - and the decision of the President of the European Patent Office of 2 November 2001 - R I/35/98 and R I/49/98, 3 July 2006, 2 BvR 1438/03 .... 288

Federal Constitutional Court, D. v. Decision of the European Patent Organization Disciplinary Board, 28 November 2005, 2 BvR 1751/03

Federal Constitutional Court, Hetzel v. Eurocontrol, 10 November 1981, 59 BvR $1058 / 79$ $173,287-288$

Federal Constitutional Court, Klausecker v. Germany, 22 June 2006, 2 BvR 2093/05

Federal Constitutional Court, S. v. the European Patent Organization, 4 April 2001, 2 BvR 2368/99 288-289

\section{Italy}

Court of Cassation, Alberto Drago v. International Plant Genetic Resources Institute (IPGRI), 19 February 2007, No. 3718 ILDC 827 (IT 2007) ......... 107, $233,285,287,296$

Court of Cassation, Cristiani v. Italian Latin-American Institute, 23 November 1985, 87 ILR 21

Court of Cassation, European University Institute v. Piette, 19 March 1999, Italian Yearbook of International Law (1999) pp. 155-157 233, 286-287

Court of Cassation, FAO v. Colagrossi, 18 May 1992, No. 5942, 75 Rivista di diritto internazionale (1992) p. 407

Court of Cassation, Instituto Nazionale di Previdenze per i Dirigenti di Aziende Industriali (INPDAI) v. FAO, 18 October 1982, United Nations Juridical Yearbook (1982) p. 234

Court of Cassation, International Institute for Agriculture v. Profili, 26 February 1931, 5 ILR 413

Court of Cassation, Italian Latin-American Institute v. Bonanni, 18 August 1990, Rivista di diritto internazionale privato e processuale (1992) p. 143

Court of Cassation, Maida v. Administration for International Assistance, 27 May 1955, Rivista di diritto internazionale (1956) 546, 23 ILR 510

Court of Cassation, Nacci v. Bari Institute of the International Center for Advanced Mediterranean Agronomic Studies, 8 June 1994, Case No. 5565, Rivista di diritto internazionale (1994) p. 837

Court of Cassation, Pistelli v. European University Institute, 29 October 2005, No. 20995, paras. 8-9, 3 Guida al diritto (2006) p. 40; ILDC 297 (IT 2005) ... 107, 
Court of Cassation, Simoncioni and Others v. Germany and President of the Council of Ministers, 29 October 2014, No. 238/2014, ILDC 2237

\section{The Netherlands}

Court of Appeal in The Hague, Mustafić et al. v. the State of the Netherlands, 200.020.173/01, 5 July 2011 22-23, 74

Court of Appeal in The Hague, The Association of Citizens Mothers of Srebrenica $v$. the State of the Netherlands and the UN (Appeal), 200.022.151/01,30 March 2010 102,298

Court of Appeal in The Hague, Vakbondsunie van het Europees Octrooibureau (VEOB, The Hague Department) \& SUEPO (Staff Union of the European Patent Office) v. the European Patent Organization (also the European Patent Office), 200.020.173/01, 17 February 2015 $281,322,333$

Court of Appeal in The Hague, Xv. European Patent Organization, No. BB5865, 06/1390, 28 September 2007

District Court in Maastricht, Eckhard v. European Organization for the Safety of Air Navigation, 12 January 1984, 94 ILR 331

District Court in The Hague, $H B, E P$ and $K S$ v. International Service for National Agricultural Research (ISNAR), 13 February 2002, 35 Netherlands Yearbook of International Law (2004) pp. 453-458

District Court in The Hague, Pichon-Duverger v. PCA, Judgment in interim incidental proceedings, 262987/02-3417, 27 June 2002 .....

District Court in The Hague, Restaurant De La Tourv. the European Patent Organization, 356198/KG ZA 10-11, 15 February 2010

District Court in The Hague, The Association of Citizens Mothers of Srebrenica $v$. the State of the Netherlands and the UN (Incidental Proceedings), 295247/HA ZA 07-2973, 10 July 2008

District Court in The Hague, Vakbondsunie van het Europees Octrooibureau (VEOB, The Hague Department) \& SUEPO (Staff Union of the European Patent Office) v. the European Patent Organization (also European Patent Office), Judgment in interim injunction proceedings, C/09/453749/KG ZA 13-1239, 14 January 2014

Supreme Court, Greenpeace Nederland and Procurator General at the Supreme Court of the Netherlands (intervening) v. Euratom, 13 November 2007, BA9173, ILDC 838 (NL 2007) 230,234

Supreme Court, Netherlands v. A and Others, [2012] LJN:BX8351, 14 December 2012, ILDC 1959 (NL 2012)

Supreme Court, Spaans v. Iran-US Claims Tribunal, 20 December 1985, Nederlandse Jurisprudentie (1986) p. 438, ILDC 1759 (NL 1985)

Supreme Court, State of the Netherlands v. Mustafić et al., 6 September 2013, BZ9228 $23,74,297$

Supreme Court, State of the Netherlands v. Nuhanović, BZ9225, 6 September 2013 23, 74, 297

Supreme Court, The Association of Citizens Mothers of Srebrenica v. the State of the Netherlands and the UN (Appeal), 10/04437, 12 April 2012, ILDC 1760 (NL 2012) 
Supreme Court, $X$ v. European Patent Organization, Case No. 08/00118, LJ

BI9632, 23 October 2009, ILDC 1464 (NL 2009) $119,173,280$

\section{Switzerland}

Court of Appeals of Geneva, E. v. T., 25 March 2009, Case No. C/18260/2005-4, unpublished

Federal Supreme Court, Consortium Xv. Switzerland, BGE 130 I 312 (partial), 2 July 2004, ILDC 344 (CH 2004) 254,272

Federal Supreme Court, Groupement Fougerolle \& Consorts v. CERN, 21 December 1992, 2 Bulletin de l'association suisse d'arbitrage (1993) p. 259; Revue de l'arbitrage (1994) p. 175 182,254

Federal Supreme Court, NML Capital Ltd and EM Limited v. Bank for International Settlements and Debt Enforcement Office Basel-Stadt, No 5A 360/2010, BGE 136 III 379 (partial), ILDC 1547 (CH 2010) 274,284

Federal Supreme Court, $X v$. International Committee of the Red Cross and Geneva Debt Collection Office, 5A_106/2012, Judgment of 20 September 2012 ... 284

Federal Supreme Court, Youssef Nada v. State Secretariat for Economic Affairs and Federal Department of Economic Affairs, 14 November 2007, Case No. 1A 45/2007, BGE 133 II 450 (2007) ILDC 461 (CH 2007) 106,295

Federal Supreme Court, ZMv. Arab League, 4 C.518/1996, 25 January 1999, Praxis des Internationalen Privat- und Verfahrensrecht (1999) pp. 257-259 ....... 254, 294

Labor Tribunal (Tribunal des prud'hommes), T. v. E., unpublished judgment of 13 October 2008, TRPH/639/2008 284

\section{United Kingdom}

High Court of Justice, Queen's Bench Division, Commercial Court, Entico Corporation Ltd v. UNESCO, 18 March 2008, [2008] EWHC 531 (Comm)

House of Lords, $R$. (On the Application of Al-Jedda) v. Secretary of State for Defence, Decision of 12 December 2007, [2007] UKHL 58

House of Lords, Arab Monetary Fund v. Hashim and others, 21 February 1991, 85 ILR 1

House of Lords, Maclaine Watson \& Co. Ltd v. International Tin Council, 26 October 1989, 81 ILR 670 225

Supreme Court, Ahmed \& Others v. HM Treasury, [2010] 4 All ER 745 ............. 308 Supreme Court, Ahmed \& Others v. HM Treasury (No. 2), Note, [2010] 4 All ER 829 308

\section{United States}

Court of Appeals for the District of Columbia Circuit, Atkinson v. Inter-American Development Bank and Kestell, 156 F 3d 1335 (DC Cir 1998), No 97-7181, [1998] USCADC 237, 332 U.S.App.D.C. 307, ILDC 1766 (US 1998) 
Court of Appeals for the District of Columbia Circuit, Marvin R. Broadbent et al. $v$. Organization of American States et al., 8 January 1980, 628 F.2d 27, 30-35 (DC Cir 1980) $257,275,317$

Court of Appeals for the District of Columbia Circuit, Mendaro v. World Bank, 27 September 1983, 717 F.2d 610, 614-15 $65,231,243,315,317$

Court of Appeals for the District of Columbia Circuit, Urban v. United Nations, 2 August 1985, 768 F2d 1497, 248 US App DC 64 (DC Cir 1985) 274-275

Court of Appeals for the Second Circuit, Brzak v. United Nations, 597 F.3d 107 (2d Cir. 2010) $246,253,306,321$

Court of Appeals for the Second Circuit, Delama Georges et al. v. United Nations et al., 15-455-cv, 19 August 2016 253, 306, 309

Court of Appeals for the Second Circuit, Filartiga v. Peria-Irala, 630 F.2d 876 (2d Cir. 1980)

Court of Appeals for the Third Circuit, OSS Nokalva, Inc. v. European Space Agency, 617 F.3d 756 (3d Cir. 2010) $251-255$

Criminal Court of the City of New York, People v. Mark S Weiner, 19 January 1976, 378 NYS 2d 966; United Nations Juridical Yearbook (1976) 249

District Court for the District of Columbia Circuit, Garcia v. Sebelius, 13 June 2012, 867 F. Supp. 2d 125, 141 (D.D.C. 2012)

District Court for the District of Columbia Circuit, Lempert v. Rice, 19 July 2013, 956 F. Supp. 2d 17, 25 (D.D.C. 2013)

District Court for the District of Columbia Circuit, Weinstock v. Asian Development Bank, 13 July 2005, U.S. Dist. LEXIS 16870 (D.D.C. 2005), ILDC 321 (US 2005)

District Court for the Eastern District of New York, Boimah v. United Nations General Assembly, 24 July 1987, 664 F Supp 69 (EDNY 1987) ........ 236, 243,

District Court for the Southern District of New York, Abdi Hosh Askir v. Boutros Boutros-Ghali, Joseph E Connor et al., 29 July 1996, 933 F Supp 368 (SDNY 1996) 238-239, 250-251

District Court for the Southern District of New York, Bisson v. United Nations and others, Decision on a report and recommendation of a US Magistrate Judge, Case no 06-6352 (SDNY 2008); ILDC 889 (US 2008)

District Court for the Southern District of New York, Delama Georges et al. v. United Nations et al., Opinion and Order, Civil Action No.

1:13-cv-07146-JPO, 9 January 2015 47, 189, 253, 306-309

District Court for the Southern District of New York, De Luca v. United Nations Organization, Javier Perez de Cuellar, Luis Maria Gomez, Armando Duque, Kofi Annan, Abdou Ciss, Oleg Bugaez, Susan R Mills and Frederick Gazzoli, 10 January 1994, 841 F Supp 531 (SDNY 1994)

District Court for the Southern District of New York, Mark Klyumel v. United Nations, 4 December 1992, 92 Civ 4231 (PKL); 1993 US Dist Lexis 20876 (SDNY 1992) 236,244

District Court for the Southern District of New York, United States v. Chalmers, 05 Cr. 59 (DC), 2007 WL 624063 244

District Court for the Southern District of New York, Van Aggelen v. United Nations, No. 06 Civ. 8240 (LBS), 2007 WL 1121744 244 
New York Supreme Court, Wencak v. United States, Special Term, 18 January 1956, (1956) 22 ILR 509 ... 42, 243

Supreme Court, Saudia Arabia v. Nelson, 23 March 1993, 507 US 349 (1993) 359 229-230, 249

Supreme Court of the State of Alaska, Price v. Unisea, Inc, 7 December 2012, 289 P.3d 914, 920

\section{Venezuela}

Political-Administrative Chamber of the Supreme Court of Justice (Sala Politico Administrativa Del Tribunal Supremo De Justicia), Sentencia No. 01967, 19 September 2001 290

Seventh Labor Court of First Instance of Caracas (Juzgado Séptimo de Primera Instancia de Juicio de Trabajo, Caracas), Francisco Franco Dorta v. FAO, 27 June 2007 
Pierre Schmitt - 9781786432896 Downloaded from PubFactory at 04/26/2023 03:29:23PM via free access 